\title{
PENGARUH PENGHARGAAN FINANSIAL, PELATIHAN PROFESIONAL, PENGAKUAN PROFESIONAL DAN PERTIMBANGAN PASAR KERJA DALAM PEMILIHAN KARIR SEBAGAI AKUNTAN (Studi Empiris Pada Mahasiswa Jurusan Akuntansi Universitas Negeri)
}

\author{
Kristin Marito Hutagalung ${ }^{1}$, Esa Setiana ${ }^{2}$ \\ Universitas Negeri Medan ${ }^{1}$, Universitas ${ }^{2}$, Universitas ${ }^{3}$ \\ Kristinhtgalung24@gmail.com ${ }^{1}$, esasetiana@yahoo.com ${ }^{2}$.
}

\begin{abstract}
Abstrak: Permasalahan dalam penelitian ini adalah Indonesia masih sangatmembutuhkan banyak akuntan, akan tetapi pada kenyataanya mahasiswa dengan lulusan akuntansi menunjukan minat yang rendah pada profesi akuntan publik Tujuan Penelitian ini adalah untuk mengetahui Pengaruh Penghargaan Finansial, Pelatihan Profesional, Pengakuan Profesional dan Pertimbangan Pasar Kerja secara parsial dan simultan dalam Pemilihan karir sebagai Akuntan.Populasi dalam penelitian ini adalah seluruh Mahasiswa Jurusan Akuntansi stambuk 2017 yang berjumlah 133 Responden. Sampel Penelitian ini menggunakan Teknik random Sampling dengan rumus slovin, sehingga diperoleh 55 Responden. Teknik analisis Data yang digunakan adalah Regresi Linear Berganda dengan dengan menggunakan alat uji statistik SPSS 25. Hasil penelitian menemukan bukti empiris bahwa Variabel Penghargaan Finansial, Pengakuan Profesional dan Pertimbangan Pasar Kerja berpengaruh Signifikan dalam Pemilihan karir sebagai Akuntan. Sedangkan Pengakuan Profesional berpengaruh tidak signifikan dalam Pemilihan karir sebagai Akuntan.
\end{abstract}

Kata Kunci: Penghargaan Finansial, Pelatihan Profesional, Pengakuan Profesional, Pertimbangan Pasar Kerja, Pemilihan Karir sebagai Akuntan.

Abstract:The problem in this research is that Indonesia still needs a lot of accountants, but in fact students with accounting graduates show low interest in the public accounting profession. The purpose of this study was to determine the effect of financial rewards, professional training, professional recognition and labor market considerations partially and Simultaneous in choosing a career as an accountant. The population in this study were all 133 students of the 2017 Accounting Department. The sample of this study used a random sampling technique with the slovun formula, in order to obtain 55 respondents. The data analysis technique used is Multiple Linear Regression with using the SPSS 25 statistical test tool. The results of the study found empirical evidence that the variables of financial rewards, professional recognition and labor market considerations have a significant effect on career choice as an accountant. Meanwhile, Professional Recognition has no significant effect in choosing a career as an accountant.

Keywords: Financial Awards, Professional Training, Professional Recognition, Labor Market Considerations, Career Selection as an Accountant. 


\section{Pengaruh Penghargaan Finansial, Pelatihan Profesional, Pengakuan Profesional dan Pertimbangan Pasar Kerja dalam Pemilihan Karir sebagai Akuntan}

\section{Pendahuluan}

\subsection{Latar Belakang}

Memasuki Era Globalisasi, Persaingan Dunia Kerja semakin berkembang dan dunia bisnis semakin pesat dengan didukung adanya Masyarakat Ekonomi Asean. Lulusan sarjana Akuntansi merupakan salah satu yang tergolong dalam angkatan kerja dituntut harus mampu meningkatkan kemampuan supaya bisa bersaing di pasar kerja. Keberadaan Masyarakat Ekonomi Asean (MEA) memberi kesempatan dan ancaman bagi karir akuntan karena menjadi salah satu profesi yang dianggap mampu bersaing dan berkompetisi.

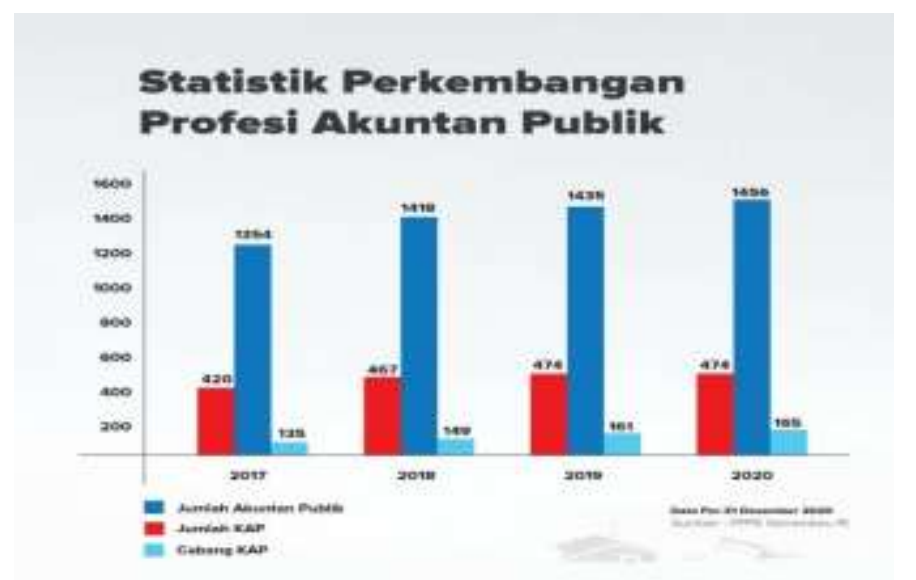

Kemenkeu memberikan penjelasan mengenai peningkatan profesi Akuntan Publik (AP) di Indonesia, yang mana peningkatanya tersebut terjadi mulai tahun 2017 - 2020, akan tetapi peningkatan yang terjadi tidak cukup signifikan. dengan berpedoman pada data IAPI kebutuhan akan adanya akuntan publik masih sangat tinggi, tercatat di tanggal 30 desember 2020 akuntan publik sebanyak 1.456 orang, serta yang mempunyai CPA (Certified Public Accountant)non akuntan publik sebanyak 2.311 orang. Jumlah tersebut sangatlah sedikit apabila dibandingkan terhadap Thailand dengan 12.000 orang yang mempunyai CPA. Apabila dibandingkan terhadap lulusan mahasiswa akutansi sebanyak 35000 setiap tahunya maka jumlah CPA adalah 3.767, hal ini menunjukan bahwa minat mahasiswa lulusan akutansi masih rendah pada akuntan publik.

Dari data tersebut dapat disimpulkan bahwa setiap tahunya jumlah tersebut mengalami peningkatan seiring dengan banyaknya lulusan sarjana akuntansi. Akan tetapi Dewan Kehormatan IAPI yaitu Sukrisno memandang lulusan akuntasi saat ini sangat sedikit yang mempunyai ketertarikan untuk menjadi akuntan publik. Memang menjadi akuntan publik resikonya sangatlah besar, yakni melakukan audit laporan keuangan perusahaan sehingga diwajibkan seorang akuntan untuk tetap independen, di sisi lain penghasilanya juga tidak sebanding terhadap resiko tersbeut(www.kompas.com).Dengan kondisi seperti itu maka memunculkan kesenjangan cukup besar antara kebutuhan dan minat mahasiswa lulusan akuntan, sehingga kesenjangan tersebut bisa jadikan peluang bagi mahasiswa akuntan lainya untuk menekuni profesi akuntan public.

Saat ini Indonesia masih sangat membutuhkan banyak akuntan, akan tetapi pada kenyataanya mahasiswa dengan lulusan akuntansi menunjukan minat yang rendah pada profesi akuntan publik, meskipun profesi tersebut mampu memberikan jenjang karir yang menjanjikan. Untuk bisa menjadi seorang akuntan publik maka seseorang tersbeut diwajibkan untuk mempunyai sertifika kelulusan USAP (ujian Sertifikasi Akuntan Publik) oleh IAPI ataupun perguruan tinggi yang sudah mempunyai akreditasi IAPI dalam melakukan penyelenggaraan pendidikan profesi akuntan publik. Dengan bermodalkan sertifikat tersebut maka akan diberikan izin praktek oleh Kemenkeu serta disebut dengan "CPA Indonesia". 


\section{Pengaruh Penghargaan Finansial, Pelatihan Profesional, Pengakuan Profesional dan Pertimbangan Pasar Kerja dalam Pemilihan Karir sebagai Akuntan}

Namun setelah dikeluarkannya UU No. 5 Tahun 20211 tentang Aakuntan Publik, Mahasiswa Program studi Akuntansi harus siap bersaing dengan Mahasiswa dari program studi non Akuntansi. Hal ini disebabkan pada BAB XI Pembinaan dan Pengawasan Bagian Kedua Pembinaan Pasal 50, mengatkan bahwa Akuntan Publik dalah yang telah mengikuti ujian sertifikasi yang dilaksanakan pemerintah (http://jdib.bpk.go.id). Sehingga menyebabkan mahasiswa dari program studi Non Akuntan dapat menjadi seorang Akuntan, apabila telah mengikuti Ujian Sertifikasi tersebut.

Sebelum memilih jadi seorang akuntan maka calon mahasiswa akutansi diwajibkan untuk memperhatikan beberapa faktor yang bisa membuat dirinya tertarik ataupun sebaliknya. Faktor yang mempengaruhi pemilihan karir akuntan publik diantaranya penghargaan finansial, hal ini adalah faktor utama yang dipertimbangkan dalam profesi ini, misalnya saja gaji gaji awal yang besar, kenaikanya cepat. Semua faktor tersebut dianggap bisa memberinya rasa puas atas pekerjaanya dalam suatu lembaga atau organisasi.Kemudian faktor kedua yang bisa memberikan motivasi bagi akuntan yaitu Pelatihan profesional. Hal ini dipandang sebuah pendidikan dengan tujuan melakukan perbaikan serta peningkatan keterampilan dan kemampuan, teguh pada nilai moral, dan ahli pada bidangnya, dengan harapan bisa menunjang pekerjaanya serta kualitas hidupnya.

Lalu faktor atau variabel yang ketiga yaitu Pengakuan Profesional. Hal ini terkait dengan adanya pengakuan dari orang lain atas sebuah kesuksesan serta pretasi dalam bidang pekerjaan tertentu. Adanya pengakuan atas pretasi dan kesuksesan suatu pekerjaan maka akan memberikan dorongan motivasi yang lebih bagi seseorang tersebut dalam pekerjaanya hingga mancapai karir yang terbaik. Dan faktor Terakhir adalah "pertimbangan pasar kerja yang mencakup keamanan kerja dengan adanya lapangan kerja atau kemudahan akses lowongan kerja. Hal ini adalah faktor dimana karir pilihanya bisa bertahan dalam rentang waktu yang lama. Dengan harapan karir bisa terus berlanjut sampai seseorang pensiun, bukan pilihan karir semata” Dwisantoso (2017).

Beberapa penelitian telah membahas mengenai pertimbangan bagi mahasiswa akuntansi dalam pemilihan karir sebagai akuntan Publik, antara lain penelitian yang dilakukan Setya abianti dan hadi pramono(2015) menunjukkan bahwa pelatihan profesional, pengakuan professional, pertimbangan pasar, lingkungan kerja, nilai-nilai sosial, personalitas tidak berpengaruh signifikan terhadap pemilihan karir akuntan publik dan non akuntan publik, sedangkan penghargaan finansial berpengaruh signifikan terhadap pemilihan karir akuntan publik dan non akuntan publik. Kemudian yang dilakukan oleh Muhammad Rido dkk (2016) mengatakan bahwa secara parsial terdapat Pengaruh signifikan dan positif antara penghargaan finansial, pelatihan profesional, pengakuan profesional, lingkungan kerja, nilai-nilai sosial, pertimbangan pasar kerja dan personalitas terhadap pemilihan karir sebagai akuntan publik dan non akuntan publik. Sedangkan secara simultan terdapat Pengaruh signifikan dan positif antara penghargaan finansial, pelatihan profesional, pengakuan profesional, lingkungan kerja, nilai-nilai sosial, pertimbangan pasar kerja dan personalitas terhadap pemilihan karir sebagai akuntan publik dan non akuntan publik.

Berdasarkan uraian-uraian diatas, maka peneliti akan mengangkat dan membahas permasalahan dengan judul Pengaruh Penghargaan Finansial, Pelatihan Profesional, Pengakuan Profesional dan Pertimbangan Pasar Kerja dalam Pemilihan karir sebagai akuntan.

\subsection{Rumusan Masalah}

Dari Latar Belakang yang telah diidentifikasi diatas, dapat dirumuskan masalah penelitian ini, antara lain:

1. Apakah Penghargaan Finansial berpengaruh dalam Pemilihan Karir sebagai Akuntan?

2. Apakah Pelatihan Profesional berpengaruh dalam pemilihan Karir sebagai Akuntan?

3. Apakah Pengakuan Profesional berpengaruh dalam pemilihan karir sebagai Akuntan?

4. Apakah Pertimbangan Pasar Kerja berpengaruh dalam Pemilihan Karir sebagai Akuntan? 


\section{Pengaruh Penghargaan Finansial, Pelatihan Profesional, Pengakuan Profesional dan Pertimbangan Pasar Kerja dalam Pemilihan Karir sebagai Akuntan}

5. Apakah Penghargaan Finansial, Pelatihan Profesional, Pengakuan Profesional dan Pertimbangan Pasar Kerja berpengaruh secara simultan dalam Pemilihan Karir Sebagai Akuntan?

\section{Kerangka Teoritis dan Pengembangan Hiotesis}

\subsection{Konsep Karir}

Secara umum, pemilihan karir adalah upaya individu untuk mempersiapkan diri pada tahapan yang berhubungan dengan pekerjaan (Agoes dan Ardana, 2009: 102). Sementara itu, Akbar (2011) mengemukakan bahwa pilihan pekerjaan atau jabatan merupakan hasil interaksi antara faktor genetik dan semua pengaruh budaya, teman, orang tua, dan orang dewasa, dan mereka dianggap memiliki peran penting. Dengan demikian, dapat disimpulkan bahwa Pilihan karir merupakan hasil interaksi personal dengan orang sekitar untuk mempersiapkan diri menghadapi tahapan yang berhubungan dengan pekerjaan.

Agoes dan Ardana (2009:103) menjelaskan proses seleksi karir yang meliputi beberapa tahapan yaitu:

a. Tahap Fantasi

Pada tahap ini, seorang memilih karirnya dengan sembarangan, bukan berdasarkan kemampuannya. Pilihan Karir dilakukan pada kekaguman dan kesan profesi.

b. Tahap Tentatif

Pada Tahap ini, seseorang mulai mengembangkan pilihan karirnya. Pertimbangan karir yang semula hanya didasarkan pada minat, tanpa mempertimbangkan faktor lain yang juga akan mempengaruhi mereka, pada tahap inilah faktor- faktor tersebut menjadi pertimbangan. Seseorang mulai memperhatikan bahwa minatnya berubah, dan mulai mempertimbangkan karier yang sesuai dengan kemampuannya.

c. Tahap realitas

Pada tahap ini, seseorang akan mengevaluasi karir yang akan dipilihnya. Kemudian melakukan penilaian berdasarkan pengalaman atau pengetahuan tentang profesi pilihannya sebagai pertimbangan untuk memasuki pekerjaan atau menentukan jurusan universitas pilihannya.

d. Tahap Eksplorasi

Orang yang terlibat dalam aktivitas yang berkaitan dengan pilihan kariernya akan berhasil atau gagal dalam fase eksplorasi. Keberhasilan atau kegagalan yang dialami akan membentuk mentalitas seseorang dan mempertimbangkan kembali karir pilihannya.

\subsection{Penghargaan Finansial}

Penghargaan Finansial adalah penghargaan yang diberikan kepada seseorang berupa uang atas kerja dan sumbangannya untuk membantu perusahaan mencapai tujuannya. Penghargaan finansial didasarkan atas asas adil dan asas layak serta wajar baik secara langsung atau tidak langsung, atas pengorbanan yang telah diberikan karyawan tersebut terhadap pencapaian tujuan organisasi/ perusahaan (Harianti,2017)

\subsection{Pelatihan Profesional}

Menurut (Saputra, 2018) Program pelatihan (training) adalah program pendidikan yang diselenggarakan secara sistematis, diselenggarakan dan dibimbing oleh tenaga profesional untuk meningkatkan keterampilan di bidang pekerjaan guna mencapai tujuan kerja yang dibutuhkan oleh perusahaan atau organisasi dan sesuai dengan kebutuhan serta Bersedia meningkatkan dan mengembangkan sikap, perilaku, keterampilan dan pengetahuan karyawan. Menurut Herawati (2015), Mahasiswa yang memilih berkarir sebagai akuntan publik akan mempertimbangkan pelatihan profesional karena Mahasiswa akuntansi yang memilih profesi untuk menjadi akuntan publik perlu 


\section{Pengaruh Penghargaan Finansial, Pelatihan Profesional, Pengakuan Profesional dan Pertimbangan Pasar Kerja dalam Pemilihan Karir sebagai Akuntan}

menjalani pelatihan kejuruan. Hal ini dikarenakan untuk menjadi akuntan publik yang dapat melakukan pekerjaan audit dengan baik, tidak hanya cukup dengan mengenyam pendidikan formal, tetapi juga harus didukung dengan jam kerja yang cukup di lapangan.Beberapa unsur pelatihan profesional antara lain: pelatihan pra kerja, partisipasi dalam pelatihan di luar organisasi, pelatihan organisasi reguler, dan berbagai pengalaman kerja (Naminingsih, 2017)

\subsection{Pengakuan Profesional}

Pengakuan profesional merupakan salah satu bentuk penghargaan non finansial terkait dengan pengakuan prestasi. Mengakui prestasi kerja akan meningkatkan kualitas pekerjaan yang dihasilkan dan meningkatkan motivasi untuk mencapai karir yang lebih baik. Profesi akuntan publik memberikan kesempatan kepada seseorang untuk berkembang, karena akuntan publik dapat ditugaskan di tempat yang berbeda dan perusahaan yang berbeda dengan karakteristik dan kondisi yang berbeda pula. Unsur-unsur pengakuan profesional meliputi pelatihan kerja, pelatihan profesional, pengakuan prestasi, pengalaman kerja yang berbeda, peluang bersaing, dan pengetahuan profesional yang dibutuhkan untuk sukses.Artinya, pengakuan profesional dapat diukur dengan kesempatan pengembangan yang diberikan, jika bekerja dengan baik, memiliki cara untuk meningkatkan diri, dan memiliki keterampilan untuk mendapatkan pengakuan.

\subsection{Pertimbangan Pasar Kerja}

Suatu hal yang pantas untuk dipertimbangkan sebelum seseorang memilih karir adalah Pasar Kerja. Saat ini Masyarakat Ekonomi ASEAN (MEA) dibuka, yang akan memberikan banyak peluang dan tantangan bagi profesi akuntan publik. Akuntan merupakan profesi yang dapat memberikan kesempatan pada lingkungan kerja saat ini, karena akuntan merupakan salah satu profesi yang diberi kewenangan untuk memberikan jasa audit (Chelz, 2010). Menurut Laraswati (2017:23), pertimbangan pasar kerja (job market consideration) mencakup empat aspek, yaitu:Tersedianya lapangan pekerjaan (Lowongan), Keamanan kerja,Fleksibilitas karir dan Kesempatan promosi

\subsection{Pengaruh Penghargaan Finansial terhadap Pemilihan karir sebagai Akuntan}

Penghargaan Finansial adalah penghargaan yang diberikan kepada seseorang berupa uang atas kinerja yang diberikan untuk membantu perusahaan mencapai tujuannya. Sistem kompensasi yang baik adalah yang mampu menjamin kepuasan para karyawan. Ketidakpuasan para karyawan terhadap kompensasi yang diterima dari organisasi akan menimbulkan dampak yang tidak baik antara lain karyawan banyak keluhan yang cenderung negatif, produktivitas kerja menurun, pemogokan karyawan dan lain sebagainya. Manusia termotivasi untuk bekerja demi memenuhi kebutuhanya, begitupun dengan minat mahasiswa akuntansi untuk menjadi akuntan publik. Mahasiswa akuntansi akan mempertimbangkan apakah dengan menjalankan profesi sebagai akuntan publik dapat memenuhi kebutuhannya yang berupa penghargaan finansial. Dalam memilih suatu pekerjaan, tentunya mahasiswa mengharapkan penghargaan finansial yang adil dan layak serta wajar dari pekerjaan tersebut. Dengan demikian penghargaan finansial yang adil dan layak serta wajar akan berpengaruh dalam pemilihan karir mahasiswa akuntansi untuk menjadi akuntan public. Hal ini didukung dengan penelitian yang dilakukan oleh Dewi (2020), ) menemukan bukti empiris bahwa Penghargaan finansial berpengaruh dalam Pemilihan Karir Sebagai Akuntan.

H1.Penghargaan finansial berpengaruh dalam Pemilihan Karir Sebagai Akuntan 


\section{Pengaruh Penghargaan Finansial, Pelatihan Profesional, Pengakuan Profesional dan Pertimbangan Pasar Kerja dalam Pemilihan Karir sebagai Akuntan}

\subsection{Pengaruh Pelatihan Profesional terhadap Pemilihan Karir sebagai Akuntan}

Pelatihan profesional merupakan pelatihan yang diberikan untuk meningkatkan kemampuan dan keahlian suatu profesi, selain itu pelatihan profesional juga merupakan suatu persiapan dan pelatihan yang harus dilakukan sebelum memulai suatu karir. Dalam memasuki dunia kerja seseorang harus memperrtimbangkan terlebih dahulu pelatihan profesional seperti apakah yang akan diberikan oeh suatu profesi yang akan ia tekuni. Semakin banyak pelatihan akan profesi akuntan maka secara tidak langsung juga akan mempengaruhi karir sebagai akuntansebaliknya semakin sedikit atau tidak pernah melakukan pelatihan professional maka akan berdampak pada pemilihan karir. Hal ini didukung dengan penelitian yang dilakukan oleh Rio (2017), menemukan bukti empiris bahwa Pelatihan Profesional berpengaruh dalam Pemilihan Karir Sebagai Akuntan.

H2.Pelatihan Profesional berpengaruh dalam Pemilihan Karir Sebagai Akuntan

\subsection{Pengaruh Pengakuan Profesional terhadap Pemilihan karir sebagai Akuntan.}

Pengakuan profesional merupakan bentuk Evaluasi dan pemberian penghargaan dalam berbagai bentuk Penghargaan untuk mengakui kinerja atau usaha seseorang yang dianggap memuaskan. Pengakuan profesional terkait dengan Pencapaian berupa prestasi dan tidak berwujud secara finansial.semakin tinggi pengakuan profesional pada Profesi Akuntan Publik maka akan meningkatkan minatmahasiswa dalam memilih profesi Akuntan Publik. Mahasiswa lebih tertarik kepada suatu pekerjaan yang memberikan pengakuan terhadap sebuah prestasi yang diraih yang mampu meningkatkan rasa semangat dari karyawan sehingga mampu meningkatkan kinerja untuk perusahaan(Dewi, 2020) Hal ini didukung dengan penelitian yang dilakukan oleh Rio (2017), dan Dewi (2020) menemukan bukti empiris bahwa Pengakuan Profesional berpengaruh dalam Pemilihan Karir Sebagai Akuntan.

H3.Pengakuan Profesional berpengaruh dalam Pemilihan Karir Sebagai Akuntan.

\subsection{Pengaruh Pertimbangan Pasar Kerja dalam Pemilihan Karir sebagai Akuntan}

Pertimbangan Pasar kerja merupakan salah satu faktor yang dipertimbangkan dalam bekerja karena setiap pekerjaan memiliki Peluang dan kesempatan yang berbeda. Apabila peluang seorang karyawan pada suatu profesi sangat kecil dikarenakan persaingan yang sangat ketat, serta ketersediaan lapangan pekerjaan sangat sedikit, maka minat seseorang untuk memilih profesi tersebut akan kurang. Sementara peluang untuk menjadi akuntan Publik masih terbuka lebar karena jumlah akuntan publik di indonesia tergolong minim. Minimnya jumlah Akuntan Publik dapat mempengaruhi Mahasiswa untuk menjadi Akuntan Publik. Hal ini didukung dengan penelitian yang dilakukan oleh Dewi (2020) menemukan bukti empiris bahwa Pertimbangan Pasar kerja berpengaruh dalam Pemilihan Karir Sebagai Akuntan

H4.Pertimbangan Pasar Kerja berpengaruh dalam Pemilihan Karir Sebagai Akuntan. 


\section{Pengaruh Penghargaan Finansial, Pelatihan Profesional, Pengakuan Profesional dan Pertimbangan Pasar Kerja dalam Pemilihan Karir sebagai Akuntan}

2.10. Pengaruh Penghargaan Finansial, Pelatihan Profesional, Pengakuan Profesional dan Pertimbangan pasar kerja dalam Pemilihan Karir sebagai Akuntan

Gambar 2.1 Kerangka Berpikir

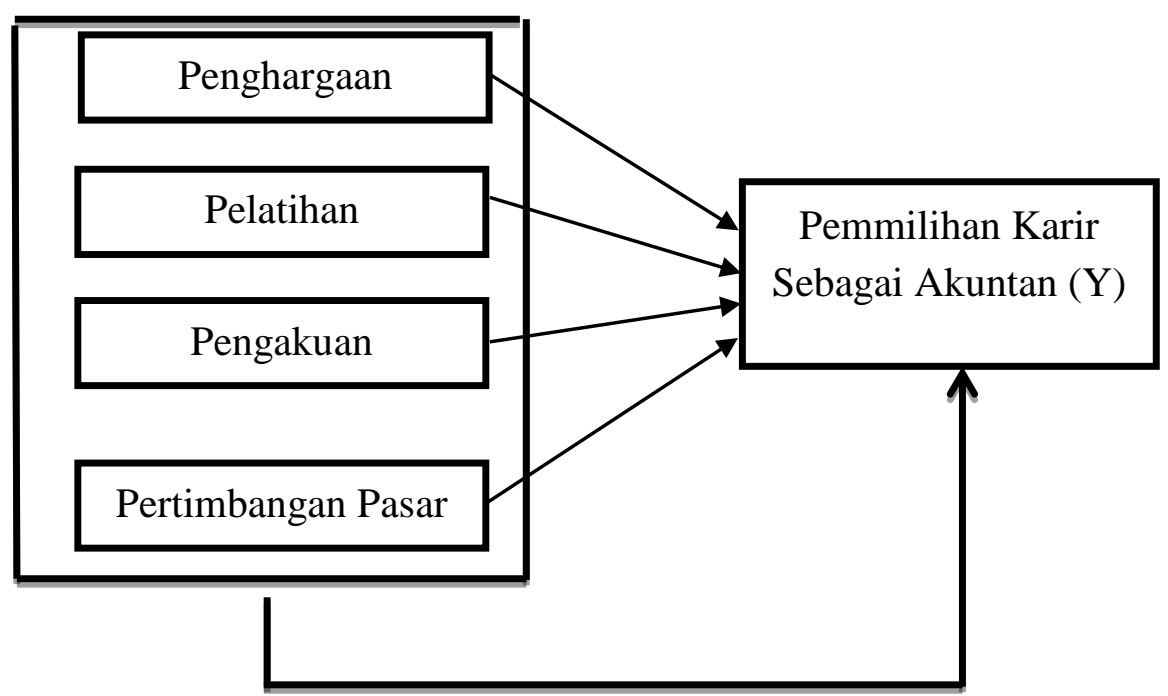

Sumber:Data yang diolah olah peneliti (2021)

\section{Metode Penelitian}

\subsection{Lokasi dan Waktu Penelitian}

Penelitian ini dilakukan di Fakultas Ekonomi Universitas Negeri Medan Jalan Williem Iskandar Psr. V -Kode Pos No.1589-Medan 20221 yang akan dilaksanakan pada semester genap tahun Ajaran 2020/2021.

\subsection{Populasi Dan Sampel}

Populasi pada penelitian ini ialah Mahasiswa Akuntansi stambuk 2017 yang berjumlah 133 Mahasiswa. Teknik Pengambilan Sampel pada penelitian ini dilakukan dengan menggunakan teknik Random Sampling yaitu sebagain dari populasi, penentuan jumlah sampel menggunakan Rumus Slovin :

$$
n=\frac{N}{1+N(e) 2}
$$

$$
n=\frac{121}{1+121(0,1) 2}=54,75 \text { dibulatkan menjadi } 55 \text { Mahasiswa Akuntansi. }
$$

\subsection{Teknik Pengumpulan Data}

Teknik Pengumpulan data yang digunakan dalam penelitian ini adalah teknik Pengumpulan data Primer, yaitu dilakukan dengan cara menyebarkan kuesioner melalui Platform Google Form. Metode Pengumpulan data yang digunakan dalam penelitian ini adalah metode dokumentasi, yaitu memperoleh data sekunder berupa populasi penelitian.

\subsection{Teknik Analisis Data}

Teknik analisis data dalam penelitian ini adalah analisis Regresi Berganda untuk memperoleh gambaran mengenai pengaruh Penghargaan Finansial, Pelatihan Profesional, Pengakuan Profesional 


\section{Pengaruh Penghargaan Finansial, Pelatihan Profesional, Pengakuan Profesional dan Pertimbangan Pasar Kerja dalam Pemilihan Karir sebagai Akuntan}

dan Pertimbangan Pasar Kerja dalam Pemilihan Karir sebagai Akuntan dengan menggunakan program SPSS (Statistical Package for Social Science Statistics). Data yang telah diterima peneliti selanjutnya diolah agar memperoelh informasi yang dibutuhkan untuk menjawab permasalahan yang diajukan. Uji yang dilakukan adalah Statistik deskriptif, Uji kualitas Data, Uji Normalitas, Multikolinearitas, uji heteroskedastisitas, uji regresi berganda, uji simultan, uji parsial dan uji koefisien determinasi.

$$
Y=a+\beta_{1} \cdot X_{1}+\beta_{2} \cdot X_{2}+\beta_{3} \cdot X_{3}+\boldsymbol{B}_{4} \cdot X_{4+} E
$$

Keterangan:

$$
\begin{aligned}
& Y=\text { Pemilihan Karir sebagai Akuntan } \\
& a=\text { Konstanta } \\
& \beta_{1,2,3,4}=\text { Koefisien Regresi } \\
& X_{1}=\text { Variabel Penghargaan Finansial } \\
& X_{2}=\text { Variabel Pelatihan Profesional } \\
& X_{3}=\text { Variabel Pengakuan Profesional } \\
& X_{4}=\text { Variabel Pertimbangan Pasar kerja } \\
& E=\text { Variabel Pengganggu (error) }
\end{aligned}
$$

\section{HasilPenelitian dan Pembahasan}

\subsection{Analisis Statistik Deskriptif}

Analisis statistik deskriptif merupakan analisa yang bertujuan untuk mengetahui gamabran umum maupun karakteristik data yang digunakan dalam penelitian ini. Hasil Pengujian statistik deskriptif dapat dilihat dari tabel 4.1.2 dibawah ini

Tabel 4.1

\begin{tabular}{|l|l|r|r|r|r|}
\hline \multicolumn{7}{|c|}{ Descriptive Statistics } \\
\hline & $N$ & \multicolumn{1}{|l|}{ Minimum } & \multicolumn{1}{l|}{ Maximum } & Mean & $\begin{array}{l}\text { Std. } \\
\text { Deviation }\end{array}$ \\
\hline Penghargaan Finansial & 55 & 14 & 35 & 26,80 & 4,519 \\
\hline Pelatihan Profesional & 55 & 10 & 20 & 14,47 & 2,410 \\
\hline Pengakuan Profesional & 55 & 9 & 20 & 14,29 & 2,492 \\
\hline Pertimbangan Pasar Kerja & 55 & 20 & 37 & 27,25 & 3,954 \\
\hline Pemilihan Karir Akuntan & 55 & 24 & 44 & 31,11 & 5,032 \\
\hline Valid N (listwise) & 55 & & & & \\
\hline
\end{tabular}

Sumber :Hasil Pengolahan Uji Data SPSS 25,2021

Berdasarkan hasil perhitungan tabel diatas menunjukkan bahwa jumlah pengamatan pada Prodi Akuntansi di Universitas Negeri Medan dalam penelitian ini dengan responden berjumlah 55 orang. Variabel Pemilihan Karir Sebagai Akuntan Publik (AP) mempunyai Mean yang diperoleh secara statistik sebesar 31,11 dengan nilai standar deviasi 5.032. Nilai minimum dari Pemilihan karir sebagai Akuntan ialah 24 dan nilai maksimum 44. Variabel Independen Penghargaan Finansial (PF), menunjukkan nilai minimum dari Penghargaan Finansial sebesar 14 sedangkan nilai Maksimum sebesar 35. Nilai Rata-Rata sebesar 26,80 lebih besar dari standar deviasi yaitu 4,519.Variabel independen Pelatihan Profesional (PP)menunjukkan nilai minimum dari Pelatihan ProfesionalSebesar 10 sedangkan Nilai maksimum sebesar 20. Nilai Rata-Rata sebesar 14,47 lebih besar dari standar 


\section{Pengaruh Penghargaan Finansial, Pelatihan Profesional, Pengakuan Profesional dan Pertimbangan Pasar Kerja dalam Pemilihan Karir sebagai Akuntan}

Deviasi yaitu 2,410. Variabel independen Pengakuan Profesional (PPR) menunjukkan nilai Minimum dari Pengakuan Profesional sebesar 9 sedangkan Nilai Maksimum sebesar 20. Nilai Rata- Rata sebear 14,29 lebih besar dari standar deviasi yaitu 2,492. Variabel Independen Pertimbangan Pasar Kerja (PPS) menunjukkan nilai minimum dari Pertimbangan Pasar Kerja sebesar 20 sedangkan nilai maksimum sebesar 37. Nilai mean sebesar 27,25 lebih besar dari standar deviasi yaitu 3,954.

\subsection{Uji Kualitas Data}

\section{a. Uji Validitas}

Pengujian validitas digunakan untuk mengukur valid atau tidaknya suatu kuesioner. Uji Valliditas dalam penelitian ini menggunakan person Correlation dengan membandingkan $r_{\text {hitung }}($ tabel person correlation ) $>r_{\text {tabel }}$ ( tabel product moment dengan tingkat signifkansi 5\% atau 0,05) Jika nilai $r_{\text {hitung }}>r_{\text {tabel }}$ maka butir atau pertanyaan/pernyataan tersebut dinyatakan valid (Ghozali, 2018:45). Untuk degree of freedom : $(d f)=\mathrm{n}-2$, dimana $(n)$ adalah sebanyak 55 responden dan besarnya $d f$ adalah 55-2 $=53$, dengan $d f=53$ dan alpha $=0,05$ dan $\mathrm{r}_{\text {tabel }}=0,265$.

\section{1) Validitas Item Pernyataan untuk Variabel Penghargaan Finansial}

Tabel 4.2

Uji validitas Penghargaan Finansial

\begin{tabular}{|c|c|c|c|}
\hline Korelasi & r hitung & r table & Keterangan \\
\hline Butir 1 & 0,712 & 0,265 & Valid \\
\hline Butir 2 & 0,829 & 0,265 & Valid \\
\hline Butir 3 & 0,788 & 0,265 & Valid \\
\hline Butir 4 & 0,793 & 0,265 & Valid \\
\hline Butir 5 & 0,663 & 0,265 & Valid \\
\hline Butir 6 & 0,801 & 0,265 & Valid \\
\hline Butir 7 & 0,624 & 0,265 & Valid \\
\hline
\end{tabular}

Sumber: Hasil Pengujian Data SPSS,2021

seluruh butir angket dari variabel Penghargaan Finansial dinyatakan Valid karena telah memenhi syarat seluruh $r_{\text {hitung }}$ lebih $>r_{\text {tabel. }}$.

2) Validitas Item Pernyataan untuk Variabel Pelatihan Profesional

Tabel 4.3

Uji Validitas Pelatihan Profesional

\begin{tabular}{|l|l|l|l|}
\hline Korelasi & r hitung & r table & Keterangan \\
\hline Butir 1 & 0,725 & 0,265 & Valid \\
\hline Butir 2 & 0,746 & 0,265 & Valid \\
\hline Butir 3 & 0,809 & 0,265 & Valid \\
\hline Butir 4 & 0,730 & 0,265 & Valid \\
\hline
\end{tabular}

Sumber: Hasil Pengujian Data SPSS,2021

Seluruh butir angket dari variabel Pelatihan Profesional dinyatakan Valid karena telah memenhi syarat seluruh $\mathrm{r}_{\text {hitung }}$ lebih $>\mathrm{r}_{\text {tabel }}$

\section{3) Validitas Item Pernyataan untuk Variabel Pelatihan Profesional}




\section{Pengaruh Penghargaan Finansial, Pelatihan Profesional, Pengakuan Profesional dan Pertimbangan Pasar Kerja dalam Pemilihan Karir sebagai Akuntan}

Tabel 4.4

Uji Validitas Pengakuan Profesional

\begin{tabular}{|c|c|c|c|}
\hline Korelasi & r hitung & r table & Keterangan \\
\hline Butir 1 & 0,715 & 0,265 & Valid \\
\hline Butir 2 & 0,745 & 0,265 & Valid \\
\hline Butir 3 & 0,677 & 0,265 & Valid \\
\hline Butir 4 & 0,702 & 0,265 & Valid \\
\hline
\end{tabular}

Sumber: Hasil Pengujian Data SPSS,2021

Seluruh butir angket dari variabel Pengakuan Profesional dinyatakan Valid karena telah memenhi syarat seluruh $\mathrm{r}_{\text {hitung }}$ lebih $>\mathrm{r}_{\text {tabel. }}$

4) Validitas Item Pernyataan untuk Variabel Pertimbangan Pasar Kerja

Tabel 4.5

Uji Validitas Pertimbangan Pasar Kerja

\begin{tabular}{|c|c|c|c|}
\hline Korelasi & (r hitung) & r table & Keterangan \\
\hline Butir 1 & 0,812 & 0,265 & Valid \\
\hline Butir 2 & 0,636 & 0,265 & Valid \\
\hline Butir 3 & 0,711 & 0,265 & Valid \\
\hline Butir 4 & 0,471 & 0,265 & Valid \\
\hline Butir 5 & 0,538 & 0,265 & Valid \\
\hline Butir 6 & 0,622 & 0,265 & Valid \\
\hline Butir 7 & 0,690 & 0,265 & Valid \\
\hline Butir 8 & 0,471 & 0,265 & Valid \\
\hline
\end{tabular}

Sumber: Hasil Pengujian Data SPSS,2021

Seluruh butir angket dari variabel Pertimbangan pasar Kerja dinyatakan Valid karena telah memenhi syarat seluruh $\mathrm{r}_{\text {hitung }}$ lebih $>\mathrm{r}_{\text {tabel. }}$.

5) Validitas Item Pernyataan untuk Variabel Pertimbangan Pasar Kerja

Tabel 4.6

Uji Validitas Pelatihan Profesional

\begin{tabular}{|l|l|l|l|}
\hline Korelasi & r hitung & r table & Ketarngan \\
\hline Butir 1 & 0,838 & 0,265 & Valid \\
\hline Butir 2 & 0,640 & 0,265 & Valid \\
\hline Butir 3 & 0,733 & 0,265 & Valid \\
\hline Butir 4 & 0,724 & 0,265 & Valid \\
\hline Butir 5 & 0,761 & 0,265 & Valid \\
\hline Butir 6 & 0,802 & 0,265 & Valid \\
\hline
\end{tabular}




\section{Pengaruh Penghargaan Finansial, Pelatihan Profesional, Pengakuan Profesional dan Pertimbangan Pasar Kerja dalam Pemilihan Karir sebagai Akuntan}

\begin{tabular}{|l|l|l|l|}
\hline Butir 7 & 0,794 & 0,265 & Valid \\
\hline Butir 8 & 0,779 & 0,265 & Valid \\
\hline Butir 9 & 0,711 & 0,265 & Valid \\
\hline
\end{tabular}

Sumber: Hasil Pengujian Data SPSS,2021

seluruh butir angket dari variabel Pemilihan Karir sebagai Akuntan dinyatakan Valid karena telah memenhi syarat seluruh $r_{\text {hitung }}$ lebih $>r_{\text {tabel. }}$

\section{b. Uji Reliabilitas}

Uji reliabilitas ini dilakukan untuk menguji konsistensi data dalam jangka waktu tertentu, yaitu untuk mengetahui sejauh mana pengukuran yang digunakan dapat dipercaya/diandalkan. Suatu instrumen dikatakan reliabel/andal jika alat ukurtersebut memberikan hasil yang konsisten, pada waktu dan kondisi yang berbeda. Dalam penelitian ini, untuk mengukur reliabilitas dari kuesioner disusun dengan menggunakan uji Cronbach Alpha. Pertanyaan yang mempunyai Cronbach Alpha lebih dari 0,60 dikatakan suatu variabel yang reliabel (Ghozali,2018:46).

Tabel 4.7

Uji Reliabilitas

\begin{tabular}{|l|l|l|l|}
\hline Variabel & Alpha Cronbach & Kriteria & Keterangan \\
\hline Penghargaan Finansial & 0,861 & Alpha Cronbach & Reliabel \\
\cline { 2 - 2 } $\begin{array}{l}>0,60 \\
\text { Pelatihan Profesional }\end{array}$ & 0,744 & Reliabel \\
\cline { 1 - 2 } Pengakuan Profesional & 0,669 & & Reliabel \\
\hline Pertimbangan Pasar Kerja & 0,768 & Reliabel \\
\hline Pmilihan Karir Sebagai Akuntan & 0,902 & Reliabel \\
\hline
\end{tabular}

Sumber: Hasil Pengujian Data SPSS,2021

\subsection{Uji Normalitas}

Uji Normalitas bertujuan untuk melihat apakah dalam model regresi variabel dependen dan independennya memiliki distribusi normal atau tidak. Uji ini dilakukan dengan menggunakan analisis statistik dan grafik. Suatu distribusi data dapat dikatakan normal apabila memiliki nilai residual (sig $>$ $0,05)$, Sebaliknya, jika nilai residual suatu data $(\mathrm{Sig}<0,05)$ maka distribusi data tidak normal.

\section{Tabel 4.8}

Uji Normalitas

One-Sample Kolmogorov-Smirnov Test

\begin{tabular}{|c|c|c|}
\hline & & $\begin{array}{c}\text { Unstandardiz } \\
\text { ed Residual }\end{array}$ \\
\hline $\mathrm{N}$ & & 55 \\
\hline \multirow[t]{2}{*}{ Normal Parameters } & Mean &, 0000000 \\
\hline & $\begin{array}{l}\text { Std. } \\
\text { Deviation }\end{array}$ & 3,75198564 \\
\hline \multirow{3}{*}{$\begin{array}{l}\text { Most Extreme } \\
\text { Differences }\end{array}$} & Absolute & 065 \\
\hline & Positive &, 065 \\
\hline & Negative &,- 044 \\
\hline Test Statistic & &, 065 \\
\hline Asymp. Sig. (2-tailed) & & $200^{\mathrm{c}, \mathrm{d}}$ \\
\hline
\end{tabular}

a. Test distribution is Normal. 


\section{Pengaruh Penghargaan Finansial, Pelatihan Profesional, Pengakuan Profesional dan Pertimbangan Pasar Kerja dalam Pemilihan Karir sebagai Akuntan}
b. Calculated from data.
c. Lilliefors Significance Correction.
d. This is a lower bound of the true significance.

Berdasarkan tabel diatas dapat diketahui bahwa nilai signifikansi sebesar 0.200. Nilai ini lebih besar dari 0,05 sehingga dapat disimpulkan bahwa nilai residual berdistribusi normal.

\subsection{Uji Multikolinearitas}

Uji Multikolinearitas bertujuan untuk menguji apakah model regresi ditemukan adanya korelasi antarvariabel bebas( independen).

Tabel 4.9

Uji Multikolinearitas

\begin{tabular}{|llcl|}
\hline \multicolumn{3}{|c|}{ Coefficients $^{\mathbf{a}}$} \\
\cline { 2 - 4 } Model & \multicolumn{2}{c|}{ Collinearity Statistics $^{\text {Tolerance }}$} & VIF \\
\hline \multirow{4}{*}{1} & & & 1.139 \\
\cline { 2 - 4 } & (Constant) & .878 & 1.351 \\
& PF & .740 & 1.135 \\
& PP & .881 & 1.379 \\
& PPR & .725 & \\
& PPS & Sumber: Hasil Pengujian Data SPSS,2021
\end{tabular}

Berdasarkan hasil uji multikolinearitas di atas dapat diketahui bahwa tidak terdeteksi multikolinearitas karena suatu model regresi dapat terbebas dari multikolinearitas jika nilai-nilai tolerance di atas 0,10 dan nilai VIF di bawah 10. Pada hasil multikolinearitas di atas nilai tolerance berada di atas 0,10 dan nilai VIF dibawah 10, sehingga model regresi tersebut terbebas dari multikolinearitas.

\subsection{Uji Heterokedastisitas}

Uji heterokedastisitas bertujuan menguji apakah dalam model regresi terjadi kesalahan penganggu (e) sehingga memiliki variance yang sama atau tidak dari pengamatan ke pengamatan yang lain.

Tabel 4.10

Uji Heterokedastisitas

\begin{tabular}{|c|c|c|c|c|c|}
\hline \multicolumn{6}{|c|}{ Coefficients $^{\mathrm{a}}$} \\
\hline \multirow[t]{2}{*}{ Model } & Unstandardize & Coefficients & $\begin{array}{l}\text { Standardized } \\
\text { Coefficients }\end{array}$ & $\mathrm{T}$ & Sig. \\
\hline & B & Std. Error & Beta & & \\
\hline (Constant) & 1.959 & 2.780 & & .705 & .484 \\
\hline PF & -.105 & .073 & -.210 & -1.440 & .156 \\
\hline $1 \overline{\mathrm{PP}}$ & .072 & .149 & .077 & .484 & .630 \\
\hline PPR & -.015 & .132 & -.016 & -.112 & .911 \\
\hline PPS & .110 & .092 & .192 & 1.196 & .237 \\
\hline
\end{tabular}

Sumber: Hasil Pengujian Data SPSS,2021

Dari tabel 4.16 diatas, dapat diketahui bahwa nilai signifikansi dari masing-masing variabel > 0,05 , hal ini menunjukkan bahwa data terbebas dari heterokedastisitas. 


\section{Pengaruh Penghargaan Finansial, Pelatihan Profesional, Pengakuan Profesional dan Pertimbangan Pasar Kerja dalam Pemilihan Karir sebagai Akuntan}

\subsection{Analisis Regresi Linier Berganda}

Regresi linear berganda bertujuan untuk melihat pengaruh dan hubungan variabel independen dengan variabel dependennya. Berikut merupakan hasil dari regresi linear berganda dalam output SPSS:

Tabel 4.11

Analisis Regresi Berganda

\begin{tabular}{|c|c|c|c|c|c|}
\hline \multicolumn{6}{|c|}{ Coefficients $^{\mathrm{a}}$} \\
\hline \multirow[t]{3}{*}{ Model } & \multirow{2}{*}{\multicolumn{2}{|c|}{ Unstandardized Coefficients }} & Standardized & \multirow[t]{3}{*}{$\mathrm{T}$} & \multirow[t]{3}{*}{ Sig. } \\
\hline & & & Coefficients & & \\
\hline & B & Std. Error & Beta & & \\
\hline (Constant) & 9.296 & 4.779 & & 1.945 & .057 \\
\hline PF & -.263 & .125 & -.236 & -2.098 & .041 \\
\hline PP & .711 & .256 & .341 & 2.780 & .008 \\
\hline PPR & .292 & .227 & .145 & 1.288 & .204 \\
\hline PPS & .528 & .158 & .415 & 3.351 & 0.002 \\
\hline a. Depen & Variabel : AP & & & & \\
\hline
\end{tabular}

Dari tabel diatas, diperoleh persamaan regresi linier berganda sebagai berikut:

$$
\mathrm{AP}=\text { 9,296- 0,263PF + 0,711PP+ 0,292PPR + 0,528PPS }
$$

\subsection{Uji Simultan}

Uji statistik F pada dasarnya menunjukkan apakah semua variabel independen atau bebas yang dimasukkan dalam model mempunyai pengaruh secara bersama-sama terhadap variabel dependen/terkait (Ghozali, 2018:99). Hasil uji simultan ditunjukkan oleh gambar 4.7 sebagai berikut:

Tabel 4.12

Uji Simultan

\begin{tabular}{|c|c|c|c|c|c|c|}
\hline \multicolumn{7}{|c|}{ ANOVA $^{a}$} \\
\hline Mode & & $\begin{array}{l}\text { Sum of } \\
\text { Squares }\end{array}$ & Df & Mean Square & $\mathrm{F}$ & Sig. \\
\hline \multirow{3}{*}{1} & Regression & 607.116 & 4 & 151.792 & 9.984 & $.000^{\mathrm{b}}$ \\
\hline & Residual & 760.179 & 50 & 15.204 & & \\
\hline & Total & 1367.345 & 54 & & & \\
\hline
\end{tabular}

Berdasarkan tabel diatas diketahui bahwa nilai $\mathrm{F}$ hitung adalah 9.984 dan sig 0,000. Karena nilai $\mathrm{F}$ hitung 9,984> F tabel 2,56, sig 0,000<0,05 maka dapat disimpulkan bahwa Penghargaan Finansial, Pelatihan Profesional, Pengakuan Profesional dan Pertimbangan Pasar Kerja berpengaruh secara simultan dalam Pemilihan Karir Sebagai Akuntan.

\subsection{Uji Parsial (t)}

Uji t digunakan untuk mengetahui pengaruh yang paling besar antara masing-masing variabel independen yaitu Penghargaan Finansial, Pelatihan Profesional, Pengakuan Profesional, dan Pertimbangan Pasar Kerja terhadap Variabel dependen yaitu Pemilihan Karir Sebagai Akuntan. 
Tabel 4.12

Uji Parsial

\begin{tabular}{|c|c|c|c|c|c|c|}
\hline \multicolumn{7}{|c|}{ Coefficients $^{\mathrm{a}}$} \\
\hline \multirow{2}{*}{\multicolumn{2}{|c|}{ Model }} & \multicolumn{2}{|c|}{$\begin{array}{l}\text { Unstandardized } \\
\text { Coefficients }\end{array}$} & \multirow{2}{*}{$\begin{array}{c}\text { Standardized } \\
\text { Coefficients } \\
\text { Beta } \\
\end{array}$} & \multirow[t]{2}{*}{$\mathrm{T}$} & \multirow[t]{2}{*}{ Sig. } \\
\hline & & B & Std. Error & & & \\
\hline \multirow{5}{*}{1} & (Constant) & 9.296 & 4.779 & & 1.945 & .057 \\
\hline & $\mathrm{PF}$ & -.263 & .125 & -.236 & -2.098 & .041 \\
\hline & PP & .711 & .256 & .341 & 2.780 & .008 \\
\hline & PPR & .292 & .227 & .145 & 1.288 & .204 \\
\hline & PPS & .528 & .158 & .415 & 3.351 & .002 \\
\hline a. & Dependent V & el : AP & & & & \\
\hline
\end{tabular}

Sumber: Hasil Pengujian Data SPSS,2021

Berdasarkan tabel 4.19 diatas dapat diketahui beberapa informasi sebagai berikut.

1. H1: Penghargaan finansial berpengaruh dalam pemilihan Karir sebgai Akuntan.

Variabel penghargaan finansial $(\mathrm{PF})$ memiliki nilai t-hitung yang lebih kecil dari nilai $\mathrm{t}_{\text {-tabel }}(-$ $2,098<2.008)$ dan taraf signifikansi yang lebih kecil dari $0,05 \quad(0.041<0.05)$. Hal ini menunjukkan bahwa variabel penghargaan finansial secara parsial berpengaruh signifikan terhadap pemilihan karir sebagai akuntan publik oleh mahasiswa akuntansi dengan kata lain, hipotesis (H1) diterima.

2. H2: Pelatihan Profesional berpengaruh dalam pemilihan Karir sebgai Akuntan.

Variabel Pelatihan Profesional (PP) memiliki nilai t-hitung yang lebih besar dari nilai $\mathrm{t}$-tabel $(2.780>2.008)$ dan taraf signifikan yang lebih kecil dari $0,05(0.008<0,05)$. Hal ini menunjukkan bahwa variabel Pelatihan Profesional secara parsial berpengaruh signifikan terhadap pemilihan karir sebagai akuntan publik oleh mahasiswa akuntansi dengan hipotesis (H2) diterima.

3. H3: Pengakuan Profesional berpengaruh dalam pemilihan Karir sebgai Akuntan.

Variabel Pengakuan Profesional(PPR) memiliki nilai $t_{\text {-hitung }}$ yang lebih kecil dari nilai $\mathrm{t}_{\text {-tabel }}$ $(1.288<2.008)$ dan taraf signifikan yang lebih besar dari $0,05 \quad(0.204>0,05)$. Hal ini menunjukkan bahwa variabel Pengakuan Profesional secara parsial tidakberpengaruh signifikan terhadap pemilihan karir sebagai akuntan publik oleh mahasiswa akuntansi dengan kata lain, hipotesis (H3) ditolak

4. H4: Pertimbangan Pasar Kerja berpengaruh dalam pemilihan Karir sebgai Akuntan.

Variabel Pertimbangan Pasar Kerja (PPS) memiliki nilai t-hitung yang lebih besar dari nilai $t_{\text {-tabel }}$ (3.351>2.008) dan taraf signifikan yang lebih kecil dari $0,05(0,00<0,05)$. Hal ini menunjukkan bahwa variabel Pertimbangan Pasar Kerja secara parsial berpengaruh signifikan terhadap pemilihankarir sebagai akuntan publik oleh mahasiswa akuntansi dengan kata lain, hipotesis (H4) diterima

4.9. Uji Koefisien Determinasi $\left(\mathbf{R}^{2}\right)$

Uji $\mathrm{R}^{2}$ mempunyai tujuan untuk mengukur seberapa jauh kemampuan model dalam menerangkan variabel dependen.

Tabel 4.12

Uji $\mathbf{R}^{2}$

\begin{tabular}{|lcccc|}
\hline \multicolumn{5}{c|}{ Model Summary $^{\mathbf{b}}$} \\
\hline Model & $\mathrm{R}$ & R Square & $\begin{array}{c}\text { Adjusted R } \\
\text { Square }\end{array}$ & $\begin{array}{c}\text { Std. Error of the } \\
\text { Estimate }\end{array}$ \\
\hline 1 & $.666^{\mathrm{a}}$ & .444 & .400 & 3.899 \\
\hline
\end{tabular}

Sumber: Hasil Pengujian Data SPSS,2021 


\section{Pengaruh Penghargaan Finansial, Pelatihan Profesional, Pengakuan Profesional dan Pertimbangan Pasar Kerja dalam Pemilihan Karir sebagai Akuntan}

Berdasarkan tabel diatas nilai koefisien determinasi sebesar $\mathrm{R}^{2}=0,400$. Nilai tersebut berarti seluruh variabel bebas, yakni Penghargaan Finasial(PF), Pelatihan Profesional(PP), Pengakuan Profesional(PPR) dan Pertimbangan Pasar Kerja (PPS) dapat menjelaskan variabel Pemilihan Karir Sebagai Akuntansebesar $40 \%$ sedangkan sisanya sebesar 60\% diterangkan/dijelaskan oleh variabel lain diluar penelitian ini.

\subsection{Pengaruh Penghargaan Finansial Dalam Pemilihan Karir Sebagai Akuntan}

Berdasarkan hasil pengujian ini diperoleh bukti empiris bahwa $\mathrm{H} 1$ diterima. Koefisien regresi berganda Penghargaan Finansial sebesar -0,263 dengan nilai signifikansi 0,041<0,05. Hal ini menunjukkan H1 terdukung, sehingga dapat dikatakan bahwa Penghargaan Finansial berpengaruh negatif signifikan dalam pemilihan karir sebagai akuntan.hal ini menunjukkan bahwa mahasiwa berharap memperoleh gaji yang adil, yakni gaji yang sebanding dengan pengorbananya dalam pekerjaan tersebut, kemudian selain adil juga harus wajar, yakni cukup untuk memenuhi kebutuhan hidupnya sesuai dengan standar kelompok masyarakat setempat dan juga berharap bisa mendapatkan Financial Reward. Apabila penghargaan finansial semakin besar dan diberikan secara adil dan layak serta wajar, maka mahasiswa akuntansi dalam pemilihan karir sebagai akuntan publik semakin tinggi. Penelitian ini sejalan dengan penelitian yang dilakukan oleh Rido dkk (2016), Harianti (2017), Manoma (2019) yang menyatakan bahwa Penghargaan Finansial berpengaruh dalam pemilihan karir sebagai Akuntan Publik

\subsection{Pengaruh Pelatihan Profesional dalam Pemilihan Karir sebagai Akuntan.}

Berdasarkan hasil pengujian ini diperoleh bukti empiris bahwa H2 Diterima. Koefisien regresi berganda Pelatihan Profesional sebesar 0,711 dengan nilai signifikansi 0,008< 0,05. Hal ini menunjukkan H2 terdukung, sehingga dapat dikatakan bahwa Pelatihan Profesional berpengaruh signifikan dalam pemilihan karir sebagai akuntan. Hal ini menujukkan bahwa dalam memilih karir sebagai akuntan mahasiswa mempertimbangkan Pelatihan Profesional dalam mendapatkan peningkatan keahlian untuk menunjang kompetensinya selain itu Mahasiswa Akuntansi menganggap perlu untuk melakukan Pelatihan kerja karena untuk menjadi seorang Akuntan Publik yang dapat melaksanakan Pekerjaan audit dengan baik, tidak cukup hanya dengan bekal Pendidikan formal tetapi juga harus ditunjang oleh Pengalaman Praktek di lapangan dengan jam kerja yang memadai. Hasil Penelitian ini konsisten dengan penelitian yang dilakukan oleh Rido dkk (2016),dan Sapariyah dkk (2020) yang menyatakan pelatihan profesional berpengaruh signifikan dalam pemilihan karir sebagai akuntan.

\subsection{Pengaruh Pengakuan Profesional dalam Pemilihan Karir sebagai Akuntan}

Berdasarkan hasil pengujian ini diperoleh bukti empiris bahwa $\mathrm{H} 3$ ditolak. Koefisien regresi berganda Pengakuan Profesional sebesar 0,292 dengan nilai signifikansi 0,204 >0,05. Hal ini menunjukkan $\mathrm{H} 3$ tidak terdukung, sehingga dapat dikatakan bahwa Pengakuan Profesional berpengaruh tidak signifikan dalam pemilihan karir sebagai akuntan.hal ini menunjukkan bahwa Mahasiswa Akuntansi Universitas Negeri Medan tidak mempertimbangkan Pengakuan Profesional pada Pemilihan Karir mereka nanti. Mahasiswa menganggap bahwa Pengakuan (Non Finansial) atas prestasi yang mereka lakukan adalah hal yang tidak perlu dipertimbangkan untuk mereka dapatkkan dari perusahaan. Karena pada realitanya mahasiswa setelah lulus kuliah menginginkan untuk langsung memperoleh pekerjaan untuk dapa memenuhi kebutuhan-kebutuhan hidupnya dibanding dengan membekali diri dengan Ujian CPA yang harus memerlukan biaya yang lebih mahal dan kinerja yang lebih.Hasil penelitian ini sejalan dengan penelitian yang dilakukan oleh Wasitasari dkk (2017), Janiman dkk (2020) yang menyatakan bahwa Pengakuan Profesional tidak berpengaruh dalam pemilihan Karir Akuntan Publik.

\subsection{Pengaruh Pertimbangan Pasar Kerja dalam Pemilihan Karir sebagai Akuntan}

Berdasarkan hasil pengujian ini diperoleh bukti empiris bahwa H4 diterima. Koefisien regresi berganda Pertimbangan pasar Kerja sebesar 0,528 dengan nilai signifikansi 0,002 <0,05. Hal ini menunjukkan $\mathrm{H} 4$ terdukung, sehingga dapat dikatakan bahwa Pertimbangan Pasar Kerja 


\section{Pengaruh Penghargaan Finansial, Pelatihan Profesional, Pengakuan Profesional dan Pertimbangan Pasar Kerja dalam Pemilihan Karir sebagai Akuntan}

berpengaruh positif signifikan dalam pemilihan karir sebagai akuntan.hal ini menunjukkan bahwa Pertimbangan pasar kerja ditandai dengan adanya lapangan pekerjaan yang tersedia, adapun dengan persaingan pasar kerja yang ketat, keamanan kerja, fleksibilitas karir serta peluang dalam memperoleh promosi.Apabila pertimbangan Pasar kerja Karier Akuntan Publik lebih baik daripada karier lainnya, berarti bisa disimpulkan minat mahasiswa akuntansi semakin besar untuk memulai karier sebagai Akuntan Publik Hasil Penelitian ini konsisten dengan penelitian yang dilakukan oleh Rido dkk (2016), Sapariyah dkk (2020) yang menyatakan bahwa pertimbangan pasar kerja berpengaruh signifikan dalam pemilihan karir sebagai akuntan.

\subsection{Pengaruh Penghargaan Finansial, Pelatihan Profesional, Pengakuan Profesional dan pertimbangan Pasar Kerja dalam Pemilihan Karir sebagai Akuntan.}

Berdasarkan hasil pengujian ini diperoleh bukti empiris bahwa H5 diterima. Nilai F-hitung sebesar 9,984 dengan nilai signifikansi $0,000<0,05$ dengan demikian hal ini dapat menunjukkan bahwa H5 terdukung sehingga dapat dikatakan penghargaan finansial, pelatihan profesional, pengkauan profesional dan pertimbangan pasar kerja berpengaruh signifikan dalam pemilihan akrir sebagai akuntan.koefisien determinasi yang menunjukkan nilai sebesar 0,444 atau $44 \%$ berarti bahwa Variasi Pemilihan karir sebagai akuntan dapat dijelaskan oleh variasi penghargaan finansial, pelatihan profesional, pengkauan profesional dan pertimbangan pasar kerja, sisanya sebesar 56\% dipengaruhi dengan variabel-variabel lainnya .

\section{Kesimpulan dan Saran}

\subsection{Kesimpulan}

Berdasarkan hasil analisis data dan pembahasan yang telah dikemukakan, maka dapat ditarik kesimpulan sebagai berikut :

1. Penghargaan Finansial berpengaruh signifikan terhadap pemilihan karir sebagai Akuntan.

2. Pelatihan Profesional berpengaruh signifikan terhadap Pemilihan Karir sebagai Akuntan.

3. Pengakuan Profesional berpengaruh tidak Signifikan terhadap Pemilihan Karir sebagai Akuntan.

4. Pertimbangan Pasar Kerja berpengaruh signifikan terhadap Pemilihan Karir sebagai Akuntan.

5. Penghargaan Finansial, Pelatihan Profesional, Pengaakuan Profesional, dan Pertimbangan Pasar Kerja berpengaruh secara simultan terhadap Pemilihan Karir sebagai Akuntan

\subsection{Saran}

Berdasarkan kesimpulan dan keterbatasan yang dirasakan oleh peneliti selama penelitian ini, maka peneliti memberikan saran untuk perkembangan penelitian selanjutnya khususnya terkait dengan topik nilai perusahaan, sehingga diharapkan penelitian selanjutnya mampu memberikan hasil penelitian yang lebih maksimal dengan mempertimbangkan saran dibawah ini:

1. Bagi Akademisi, lebih meningkatkan motivasi kepada mahsiswa untuk berkarir sebagai Akuntan dengan cara memberikan atau memfasilitasi Mahasiswa untuk mengikuti seminar atau Pelatihan-Pelatihan.

2. Bagi peneliti selanjutnya, sebaiknya menggunakan teknik wawancara agar dapat mengambil kesimpulan lebih tepat mengenai jawaban yang diberikan responden.

3. Peneliti selanjutnya diharapkan agar memperluas cakupan populasi dan sampel yang digunakan, tidak hanya pada satu Universitas saja agar memperoleh hasil yang lebih baik.

4. Kemudian saran yang bisa diberikan kepada peneliti selanjutnya yaitu lebih memperdalam pembahasan tentang berbagai faktor yang bisa memberikan pengaruh kepada mahasiswa dalam memilih karir sebagai akuntan seperti Lingungan Keluarga, Personalitas dan lain-lain. 


\section{Pengaruh Penghargaan Finansial, Pelatihan Profesional, Pengakuan Profesional dan Pertimbangan Pasar Kerja dalam Pemilihan Karir sebagai Akuntan}

\section{Referensi}

Abianti, S. and Pramono, H., 2015. Faktor-faktor yang berpengaruh dalam memprediksi Pemilihan Karir Akuntan Publik dan Non Akuntan Publik (Studi Pada Mahasiswa Akuntansi Perguruan Tinggi Di Purwokerto). Kompartemen: Jurnal Ilmiah Akuntansi, 13(1).

Agoes, Sukrisno dan Ardana, I Cenik. (2009). Etika Bisnis dan Profesi: Tantangan Membangun Manusia Seutuhnya. Jakarta: Salemba Empat.

Dwisantoso, Arif. 2017, Analisis Faktor-faktor yang mempengaruhi minat mahasiswa untuk berkarir menjadi akuntan publik (studi kasus pada Mahasiswa Akuntansi Universitas Muhammadiyah Surakarta).Skripsi. Surakarta: Program Strata 1 Jurusan Akuntansi Fakulta Ekonomi dan bisnis Universitas Muhammadiyah Surakarta.

Ghozali, Imam. 2018. Aplikasi Analisis Multivariate dengan Program SPSS. Edisi Sembilan. Semarang : Badan Penerbit Universitas Diponegoro.

Harianti, S. S. (2017). Pengaruh Penghargaan Finansial, Pertimbangan Pasar Kerja Dan Lingkungan Keluarga Terhadap Minat Menjadi Akuntan Publik (Studi Empiris Mahasiswa S1 Akuntansi Universitas Negeri dan Swasta Kota Padang). Jurnal Akuntansi, 5(1).

Herawati, Lily 2015. "Analisis faktor-faktor Yang Mempengaruhi Minat Mahasiswa Akuntansi Berkarir Sebagai Akuntan Publik (Studi Pada Mahasiswa Akuntansi Perguruan Tinggi Negeri di Medan)", Skripsi, USU.

http://jdib.bpk.go.id

https://pppk.kemenkeu.go.id

Janiman dan Asep Basuki, 2020. Faktor-Faktor Yang Mempengaruhi Mahasiswa Akuntansi Dalam Pemilihan Karir Menjadi Akuntan Publik.Syntax Idea

Laraswati, Amelia (2017). " Faktor-Faktor yang mempengaruhi minat mahasiswa jurusan akuntansi untuk berkarir dibidang perpajakan. Jurnal Universitas Trisakti.

Murdiawati, Dewi (2020). Faktor-Faktor Yang Mempengaruhi Minat Mahasiswa Akuntansi Di Surabaya Untuk Memilih Karir Menjadi Akuntan Publik

Naminingsih, Nana Naraika (2017). "Pengaruh Penghargaan Finansial, Pelatihan Profesional, Pengakuan Profesional, Pertimbangan Pasar,Teman Dan Keluarga Dalam Pemilihan Karir Akuntan Publik (Studi pada Mahasiswa Akuntansi Syariah di IAIN Surakarta)".Skripsi

Pemerintah Indonesia.2011.Undang-Undang Republik Indonesia Nomor 5 Tahun 2011 tentang Akuntan Publik.Lembaran Negara RI tahun 2011.Sekretariat Negara.Jakarta

Sapariyah, R.A., Putri, I.S. and Fujianto, R.L., 2020. Pengaruh Penghargaan Finansial, Pelatihan Profesional, Pengakuan Profesional, Dan Pertimbangan Pasar Kerja Terhadap Pemilihan Karir Akuntan Publik Pada Mahasiswa Akuntansi Di Perguruan Tinggi Surakarta”. Financial: Jurnal Akuntansi, 6(1), pp.98-104.

Saputra, A. J. (2018). Pengaruh Persepsi Mahasiswa Akan Minat, Motivasi, Pelatihan Profesional, Gender Dan Lingkungan Pekerjaan Terhadap Pilihan Karir Akuntan Publik Dan Non Publik. Jurnal Riset Akuntansi Mercu Buana, 4(2), 126.

Sugiyono. 2014. Metode Penelitian Kuantitatif Kualitatif dan R\&D.Bandung: Alfabeta

Warsitasari, I. A. T. S., \& Astika, I. B. P. (2017). Pengaruh Motivasi, Persepsi, Penghargaan FInansial, Pasar Kerja dan Pengakuan Profesional Pada Pemilihan Karir Akuntan Publik. EJurnal Akuntansi, 21(3), 2222-2252.

$\underline{\text { www.iapi.or.id }}$ 